American Journalism Review 28 (6): 63-7.

Kent, Jeffrey. 2008. Interview with author. February 14.

Kenyon, Linda. 2008. Interview with author. February 14.

Kornacki, Olga Ramirez. 2008. Interview with author. February 8.

Kucinich, Jackie. 2006. "Camera Use Splits Capitol Reporters.” The Hill, May 16. thehill. com (February 7, 2008).

Layton, Charles. 2007. "The Video Explosion." American Journalism Review 29 (6): 24-31.

Lewis, Truman. 2007. "Senate Press Gallery Ejects Consumer Journalist." ComsumerAffairs.com, May 9. www.consumeraffairs.com/ news04/2007/05/senate_press03.html (February 7,2008 ).

McIntee, Michael. 2007. "How to Apply for Republican National Convention Blogging Credentials." The UpTake, December 4. theuptake.org/?cat=10 (February 19, 2008).
Mayhew, David R. 1974. Congress: The Electoral Connection. New Haven: Yale University Press.

Newmyer, Tory. 2006. "Press Gallery Tensions Simmer." Roll Call, May 30. www.lexisnexis. com (February 7, 2008).

Obey, Doug. 1996. "Cyber-Reporter Denied House Press Gallery Credentials." The Hill, February 7. www.lexisnexis.com (February 2, 2008).

Pershing, Ben. 2003. "Rules Overhaul Proposed for Daily Press Galleries.” Roll Call, January 20. www.lexisnexis.com (February 17, 2008).

Ritchie, Donald A. 1991. Press Gallery: Congress and the Washington Correspondents. Cambridge, MA: Harvard University Press. 2005. Reporting from Washington: The History of the Washington Press Corps. New York: Oxford University Press.

_. 2007. "The Historical Symbiosis of Congress and the Press Galleries." Lecture to the 2007-2008 Class of APSA Congressional Fellows, November 13, Johns Hopkins University, Washington, D.C.

- 2008. Interview with author. February 7.

Senate Daily Press Gallery. 2008. What We Do. www.senate.gov/galleries/daily/whatwedo. html (February 6, 2008).

Senate Press Photographers' Gallery. 2008. Rules Governing Gallery. www.senate.gov/galleries/ photo/rules.html (February 6, 2008).

Senate Radio-Television Gallery. 2008. Executive Committee. www.senate.gov/galleries/radiotv/ exec.htm (February 6, 2008).

Stelter, Brian. 2007. "ABC News and Facebook in Joint Effort to Bring Viewers Closer to Political Coverage." New York Times, November 26. www.nytimes.com/2007/11/26/ technology/26abc.html?scp=1\&sq=facebook+ election\&st=nyt (February 21, 2008).

Taylor, Andrew. 2008. Interview with author. February 14.

\title{
Professor Emeritus of Political Science at Yale and APSA Congressional Fellow in Inaugural 1953-54 Class H. Bradford Westerfield Dies at 79
}

\section{Jeffrey Biggs, Director, Congressional Fellowship Program}

On January 19, 2008, long-time APSA member and Damon Wells Professor Emeritus of political science at Yale University H. (Holt) Bradford Westerfield died from complications of Parkinson's disease in Watch Hill, Rhode Island. He was 79. Douglas Martin's obituary in the January 27 issue of The New York Times provided a full account of his illustrious career, the details of which do not need to be repeated here. The APSA archives would not, however, have included the fact that over four decades of teaching at Yale, from 1957 when he joined the faculty as an assistant professor of international relations until his retirement in 2001, Professor Westerfield's largely undergraduate classes attracted some 10,000 students. Those classes included President Bush, Vice President Dick Cheney, Senators John Kerry and Joseph I. Lieberman, and other public officials who "... . cited his influence in framing their approach to public policy. Mr. Cheney repeatedly said Dr. Westerfield helped shape his hard-line approach to foreign policy. But an article in The Nation in 2004," noted Martin, "reported that Dr. Westerfield came to regret the hard-nosed lessons Mr. Cheney said he had learned. Dr. Westerfield explained that his own politics had become much more dovish since."

Martin's obituary did note the Professor Westerfield "spent a year studying Congress as a fellow of the American Political Science Association." That formative experience deserves more elaboration. H. Bradford Westerfield was a member of the APSA Congressional
Fellowship's inaugural 1953-54 class that included six political scientists and one journalist. He arrived as a 25-year-old instructor at Harvard University who was deeply interested in foreign affairs. At the time, the fellowship divided the congressional working experience between a committee staff and a personal staff. Westerfield served on the personal staff of Rep. Brooks Hays of Arkansas and the Senate Foreign Relations Committee, which resulted in a predictable contrast.

According to a 1954 Washington Post article ("Hill 'Interns' Find It's a Busy Grind" by Abbie and Raymond J. Blair), "he got a big dose of Congress as an informational 'mail-order' house. 'Why, during November alone,' he said, 'we were averaging 500 separate requests per day for a single committee report. In fact, most of the people in and around Congress are spending most of their working hours informing citizens in thousands of ways about thousands of things.", "On a committee staff," Westerfield was quoted, "you work in a single area. You need that to contrast with the work with a Congressman where you're doing everything at once. It points up again," he said, "what different kinds of work you can be doing and still be working for Congress."

The first class of APSA Congressional Fellows came away with one predominating feeling: "The American Government, they're convinced, really is responsive to the individual. Even in this day of $\mathrm{H}$ bombs and crises in Indochina, congressmen are brought back continually to the day-to-day needs of their constituents, when they get letters like this one that came in not long ago: 'Now it's time Congress stopped worrying about hydrogen bombs and got down to solving some of our really serious problems. Like, when are you going to pass a law to do something about poison ivy and ragweed?"'

A May 10, 1953, Washington Post article ("Congressional Interns") noted that the group could serve "a national purpose of much wider scope than their own enlightenment ... if they go into teaching, law or politics, their knowledge of how Congress operates will probably be widely diffused and thus add to public education on a subject of great importance to the success of our form of government." Professor Westerfield's long career in political science was a magnificent case in point.

He was a descendant of William Bradford, second governor of Plymouth Colony, and was born on March 7, 1928, in Rome, Italy, where his father, Ray Bert Westerfield, an economics professor at Yale, was on sabbatical. In addition to his wife, the former Carolyn Elizabeth Hess, and his son, Leland, Professor Westerfield is survived by his daughter, Pamela Westerfield Bingham, of Manhattan; his brother, Putney, of Hillsborough, California, and four granddaughters.

Please see the In Memoriam section on page 413 for another tribute to $D r$. Westerfield's scholary work by friend and colleage Bruce Russett. 